UDC 709.4; 710.5

Nataliia P. Tmienova

$\mathrm{PhD}$ in Physics and Mathematics, Associate Professor, Department of Intelligent and Information Systems Taras Shevchenko National University of Kyiv, Kyiv, Ukraine

ORCID ID 0000-0003-1088-9547

tmyenovox@gmail.com

Bogdan B. Sus

$\mathrm{PhD}$ in Physics and Mathematics, Assistant Professor, Department of Nanophysics of Condensed Matter

Taras Shevchenko National University of Kyiv, Kyiv, Ukraine

ORCID ID 0000-0002-2566-5530

bnsuse@gmail.com

\title{
TECHNOLOGIES IMPROVING FOR KNOWLEDGE AND SKILLS ASSESSING OF STUDENTS OF PHYSICAL AND MATHEMATICAL SPECIALTIES IN E-LEARNING
}

\begin{abstract}
Although the problems of obtaining educational information in e-learning have been successfully resolved, the testing of obtained knowledge still requires a solution. Principles of knowledge assessment by means of tests in mathematics subjects administered in e-learning environment have been developed. An algorithm of component analysis and formula expression indexing for automatic analysis is suggested. This approach allows diversifying the types of questions for consequent verification of knowledge in computer systems. Modification of the formula editor provides the creation of templates for formula entering and the use of indexing algorithm of the expression elements. This makes it possible to avoid ambiguity of responses entered by students. Tasks with computer verification of an analytical symbolic expression can be applied to automate the verification of skills and knowledge in natural sciences, in particular, physics, mathematics, by appropriate modification of the template.

Development of information technologies led to the development of new models of teaching and learning, especially in the field of mathematical sciences. It is shown that during experimental laboratory work in engineering subjects especially effective are those activities that combine the use of knowledge and skills acquired during the study of other related disciplines. It is shown that research based on interdisciplinary interaction has great potential.

In addition, the application and advantages of expert systems in open education to improve the teaching-learning process are discussed. It is proposed to use expert systems in the designing of laboratory works and tests. It is also shown how expert systems should be used to optimize the process of creating adaptive type laboratory works and to formulate individual test tasks. The application of the expert system is illustrated on the example of Discrete Mathematics.
\end{abstract}

Keywords: testing; automatic analysis; IT-technologies; interdisciplinarity; e-learning; expert systems.

\section{INTRODUCTION}

The development of science and information technology demands higher standards of the education quality. E-learning or distance education requires modernization and creation of new training courses, which is especially important in natural and engineering sciences. Electronic learning environments can greatly improve educational process.

If the problems concerning receiving educational information through e-learning are resolved in one way or another, the testing of knowledge remains an important problem. The most used methods of testing are paper-based and computer-based tests. Research has shown that computer testing is the most objective and technological tool for the evaluation of knowledge.

Learning Management Systems have the function of testing knowledge, but in practice, their capabilities are very limited and have a number of disadvantages. Practically all the 
educational systems include standard closed and open forms of test tasks. The most common types of computer based testing of knowledge are the following forms of test tasks: single and multiple-choice questions and matching questions [1]. Test questions of an open form give the opportunity to manufacture the answer or complete a partial answer. They do not include the proposed answer options and are often used to identify knowledge of methods for solving tasks, terms, definitions, and concepts presented in the learning material. Tests are used quite actively in the Learning Management Systems, in particular in the open source learning system Moodle (Modular Object-Oriented Dynamic Learning Environment), which is used in more than 100 countries of the world. An important feature of Moodle is that the system creates and stores the personal working environment of each student (all activities done by the student, the teacher's ratings and comments on the student's work, messages on the forums, etc.). In addition, the important fact is that this system is an open source software. It can be easily adapted to the needs of a particular educational institution [2].

To test the level of knowledge in e-learning courses in the Humanities, the closed type questions can be sufficient. In the development of laboratory work on natural sciences, closed type questions are ineffective because they do not provide verification of a number of tasks that ultimately have a formula expression required for testing knowledge. While checking answers to open-type questions, we also encounter the problem of ambiguity of responses because the same formula can be written in a different way. The article describes an algorithm that allows solving these problems and improving the existing e-learning systems and the quality of educational services.

Improvement of the quality of education in IT technology and science can be achieved by the introduction of IT teaching methods, including the use of electronic laboratories as components of e-learning systems or independent modules. Such laboratories are associated with the use of innovative information technology in the teaching of mathematical disciplines. At present, research on the basis of interdisciplinary approach has great prospects.

Now mathematics is closely linked with natural sciences. It plays a special role in the training of future specialists in the field of natural sciences, computer and information technologies. The use of e-learning systems in such case has very limited possibilities. Teachers face the task of creating a very large number of laboratory works with various ITtechnologies that are usually time consuming.

It is possible to implement expert systems to optimize the process of creating adaptive type labs and formulate individual test tasks for theoretical knowledge assessment. Expert systems provide the opportunity to structure the learning content in accordance with the analysis of responses in the course of students' independent study. In addition, these systems can offer a set of competencies that students need to master for the development of a particular method or software product.

The article reviews these important issues and describes ways of improving work with the Learning Management Systems.

Analysis of recent studies and publications. Problems related to knowledge assessment have been repeatedly raised in articles related to e-learning. V.S. Avanesov [1] has paid considerable attention to the issue of creating qualitative test tasks. Yu.S. Zharkikh, S.V. Lysochenko, B.B. Sus and O.V. Tretyak [3] have indicated that the means of computer testing can greatly facilitate the routine verification of solutions of a large number of mathematical examples in a wide audience of students.

Kirsten L. Huff \& Stephen G. Sireci [4] have discussed the analysis of the validity of computer tests compared with the classical ones. For the first time, N.P. Tmienova and B.B. Sus [5] have described an algorithm for component analysis of formulas for systems of electronic testing of knowledge in natural sciences. 
British expert Konrad Wolfram (one of the authors of "Mathematica"), known for his work in the field of information technologies and applications, has spoken about the special role of mathematics in preparing future specialists in the field of natural sciences, computer and information technologies in his lecture "How to teach the true mathematics using a computer" [6]. He states that we have big problems with mathematical education. "In fact, nobody is satisfied. Those who study mathematics believe that it is not related to real life, is uninteresting and difficult in learning. Those who are trying to take graduates to work believe that their knowledge is not enough". The combination of modern teaching methods is very relevant in the field of technology education. This especially helps to master the material of a mathematical nature. Interdisciplinary combination of skills is one of the approaches that assists in the assimilation of the received information. It is an important factor in the development of certain laboratory activities, especially related to natural sciences. B. Sus, N. Tmienova, I. Revenchuk, V.Vialkova [7] have shown the effectiveness and value of application of interdisciplinary approach to the creation of laboratory work in engineering disciplines.

N.A. Baranova [11] has emphasized the relevance of using expert systems in continuous pedagogical education. Khanna, Satvika, Kaushik, Akhil, Barnela, Manoj [9] have shown that expert systems are becoming increasingly important in education, have become an integral part of engineering education and are among the best tools for e-learning in natural sciences. In addition, it is shown that the use of expert systems in e-learning enables the optimal planning of the curriculum and decision-making, students' record management and consultation of teachers. The authors recommend the use of expert systems in studies to optimize the process of creating adaptive type laboratory works and to formulate individual test tasks for verification of theoretical knowledge.

In our opinion, the main problems and tasks related to the use of information technology, e-learning and testing systems in the study of natural sciences and mathematical disciplines can be divided into three large groups.

The first group is associated with the problem of assessing knowledge while testing students in natural sciences using open-type questions. Only through this type of questions you can check students' knowledge and skills. However, using open-type questions, we meet some problems of a different nature. These problems will be discussed in detail in the article. The second group is related to improvement of the teaching of mathematical disciplines to students of IT specialties, physics and biology. The introduction of IT teaching methods, including e-learning and the wide use of electronic laboratories, greatly facilitates educational process. As a result of the introduction of IT teaching methods, there may be a third problem associated with the optimization of the process of laboratory work development. One of the ways to overcome it is to use expert systems.

The purpose of the article. Computer-based testing technologies can significantly facilitate the routine checking of a large number of mathematical examples solutions in a wide audience of students [3]. By mission, test tasks can be divided into theoretical (knowledge test) and practical (testing skills). The quality of the test depends on the ordering of the test questions, their depth and completeness of educational material coverage. Properly compiled tests can be applied for evaluation not only of the ability to reproduce certain information, but also to compare, analyze and interpret facts.

In determining the level of students' knowledge in mathematical disciplines, the testing of skills and abilities should be emphasized. Answers to questions in a problem are usually given as formulas. In this case, the use of closed-type questions is not enough. However, there is another problem with the use of open-type questions - the problem of ambiguity of answer 
representation, when each answer is correct, since the same formula can be written in a different way. For example, the expressions $\left(x^{-1}+y^{2}\right)^{-1}$ and $\frac{1}{y^{2}+\frac{1}{x}}$ are equal.

The important feature of most Learning Management Systems (for example, Moodle) and visual editors of formulas is that they are written on an open source code. It makes them very easy to modify [2]. This can be done by educational institutions on their own. Moreover, such projects can attract students with appropriate programming skills.

The main purpose of the research is a modification of the formula editor, which involves creation of special templates for input of formulas and uses the elements indexing of the formula expression. It makes it possible to avoid ambiguity in a student's response expression. On the other hand, the use of e-learning systems, information and communication technologies in the creation of laboratory works and tests requires new approaches to improve their quality and optimize the process of their construction. This leads to the following tasks:

1) to show what appropriate methods should be used in the teaching of mathematical disciplines to students majoring in various natural sciences; in particular, to find out how the interdisciplinary approach should be applied during laboratory work;

2) to analyze the experience and benefits of expert systems in the open education system to improve the quality of the learning process and increase its effectiveness.

\section{RESULTS OF THE RESEARCH}

\subsection{Modification of formula editor}

Our suggested approach implicates the modification of the formula editor and involves the creation of templates for formula entering and the use of element indexing in the formula expression [5].

An example of the window for formula entering is shown in Figure 1:

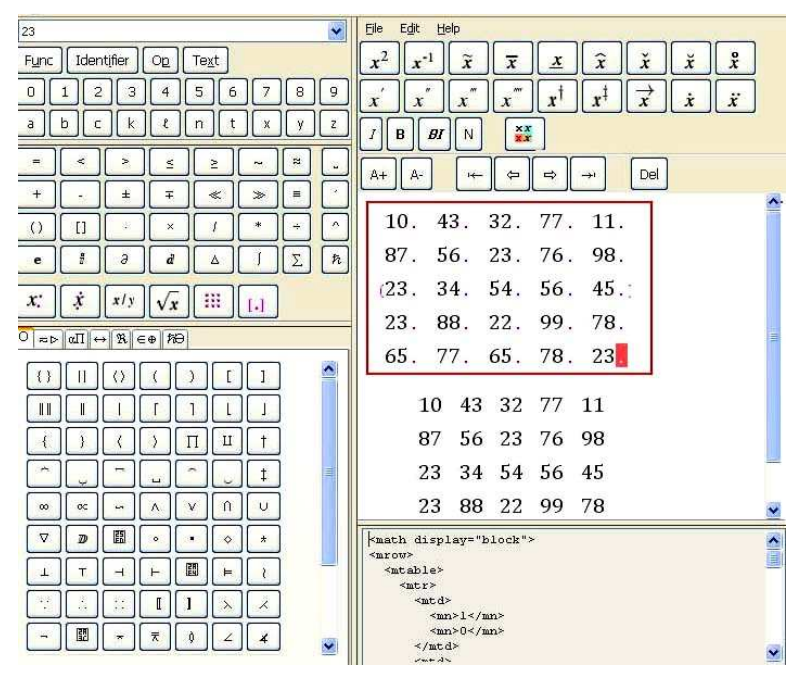

\section{Figure 1. Window for formula entering}

The data validation algorithm makes it possible to test the theoretical or practical understanding of the subject in the case of ambiguity, when students enter the response. The main steps of the algorithm's functioning are indexing array elements in groups, checking commutative, associative, and distributive operations. The proposed algorithm foresees the formalization of the introduced content. It includes the representation of the elements of the 
formula expression in a structured, suitable for computer processing form, for further processing and comparison with the reference value (using a probabilistic approach to assessment of the level of students' knowledge).

The data validation algorithm can be represented as an expanded scheme as in Figure 2:

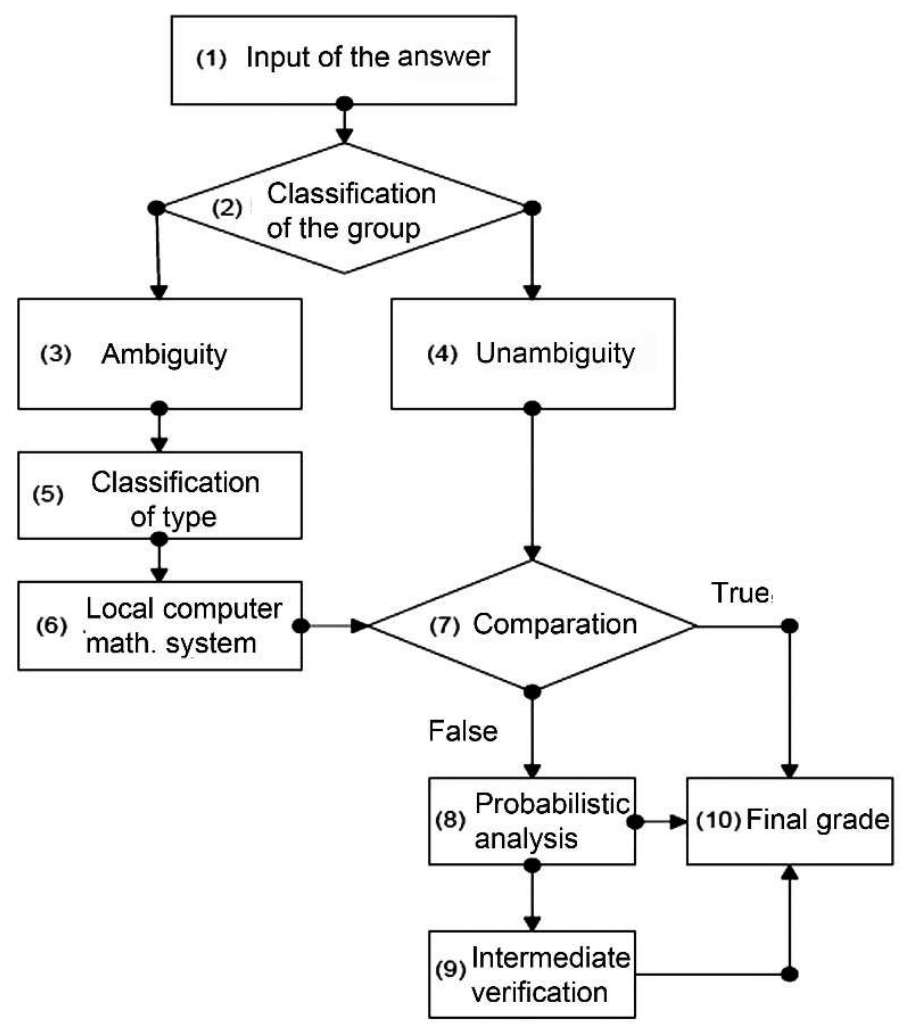

Figure 2. Scheme of the algorithm

The response entered with the extended template (1) enters the preprocessing block (2), where the classification of the task group (e.g., algebra, analytic geometry, mathematical analysis, differential equations, etc.) is carried out by analyzing the indexed values of the visual editor and checking the teacher's label (which contains information on the unambiguity or ambiguity of the entered answer).

According to the results of the analysis, unambiguous answers are tested in a simplified form for comparison with the standard (7). Depending on the probability of coincidence (8), an estimation is set (10) or an additional checking of intermediate results is proposed (9). At the same time, a corresponding penalty factor is added to the resulting evaluation. In the case of ambiguity of the answer the classification is implemented using the block (5) and the library of the system of computer mathematics (CMS), located on the local server (6).

During the test development, a teacher can assign the corresponding labels in the form of input for a detailed analysis (5) and send questionable results to the external server. Also, the instructor can indicate which area the question belongs to. This simplifies further automated verification in case of ambiguity, as the task immediately enters the corresponding library block (6). The results are sent to the block (7) or to the external server for detailed analysis.

This feature is optional because such an analysis usually requires powerful computing resources and takes a lot of time during testing of large groups of students.

The structure of the block (6) is shown in Figure 3. 


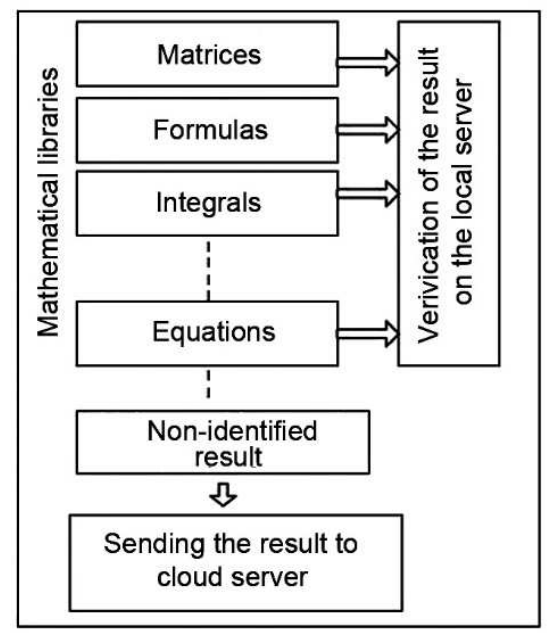

Figure 3. Structure of the block (6) "Local CMS"

The scheme in Figure 4 realizes the ability of adaptive learning. The main idea is that a student's incorrect answers are recorded in the database for the next test. After processing of the theoretical material, these questions (along with other questions from the task bank in the appropriate ratio, set by the teacher) are offered for another testing. The task is removed from the data bank only after the correct answer. The number of possible tests depends on the rating for the previous test.

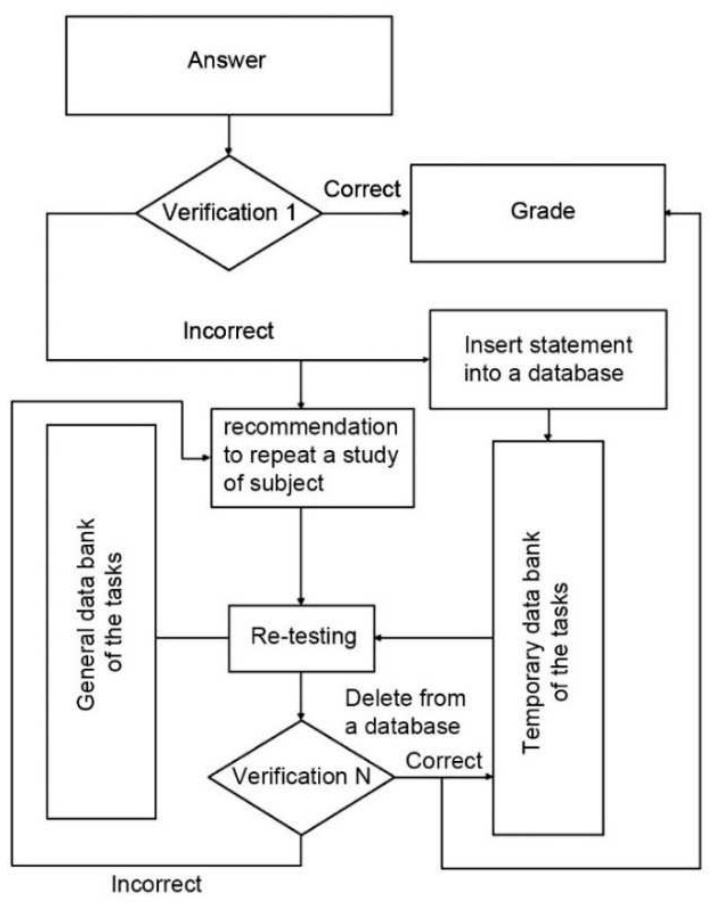

Figure 4. Scheme of students' adaptive learning

\subsection{Features of development of an e-learning course in mathematics}

Methods of mathematical disciplines are widely used in solving applied problems in the fields of physics, chemistry, biology, economics, medicine and IT industry. It is often necessary to deal with the solution of certain systems of linear equations. The main methods for solving 
systems of linear equations are the Gauss's and the Cramer's methods. Gauss's method consists in successive elementary transformations over the rows of the extended matrix of the system.

The Cramer method is usually applied to square systems of linear equations. It reduces the calculation of a large number of determinants, usually numerical. If these calculations are made manually, a large amount of time is spent even for one system. If there is a need to explore several systems, the amount of spent time significantly increases. So, research universities often have to carry out laboratory studies, which are accompanied by a number of calculations of different types. The work can be simplified by specialized programs or Internet services such as Wolfram Alpha. They allow performing similar types of operations of the same type.

To facilitate the work with such specialized software, special educational videos have been created. They contain a detailed description of the sequence of steps that must be performed to obtain the desired result with some mathematical objects (Figure 5).

The use of the software in educational process reduces the time of algorithmic calculations. On the other hand, the use of such services is also important because the visual model allows better assimilation of the relevant theoretical content. The visual perception of information increases the motivation for learning and intensifies it.

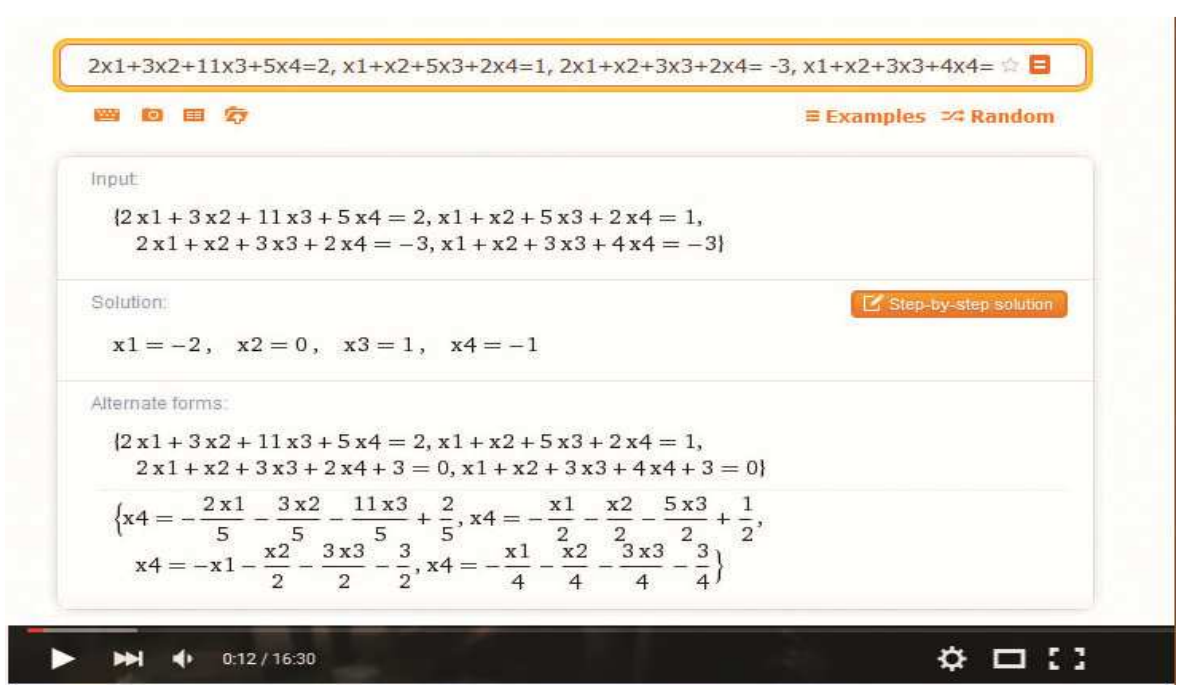

Figure 5. An example of a developed educational video

\subsection{Implementation of an interdisciplinary approach in performing laboratory work in engineering disciplines}

During laboratory activities in engineering disciplines, practical tasks that combine the use of knowledge and skills acquired in the study of related disciplines have special value and effectiveness. Let us consider this on the example of laboratory work which shows how the interdisciplinary combination of Computer Graphics, Electronics, Microprocessor Systems Architecture and Algebra is used.

One of the important tasks of radio engineering is the transmission of signals as oscillations that carry information. The main task of information technology is the processing of information. Engineers and other professionals must be able to properly design high-speed digital devices and validate such designs. Laboratory practices contribute to the acquisition of appropriate skills of the researcher and the experimenter, and therefore are very important in the learning process.

In carrying out the cycle of laboratory works on computer graphics students in practice master the methods of analysis of complex signals, which are studied in the courses of 
electrical engineering and circuit engineering, where they are acquainted with deterministic, random, analog, discrete and digital signals [7]. For example, in the study of transient processes in electric circuits, the analysis of time and spectral characteristics of signals, the study of the passing of different signals through the circles of the first and second order, analog oscilloscopes are usually used to visualize the form of electrical and other signals in graphical form. By examining the signals displayed on the oscilloscope's screen, students can determine how the components of the electronic circuit function correctly. To understand the principles of the oscilloscope it is important to know the theoretical basis of the analysis of signals. Recent advances in telecommunications, the creation of powerful microcontrollers and the transition to digital technology greatly enhance the possibilities of visualization of complex processes.

Problem based approach is used in the proposed laboratory work. Initially after a discussion on how to solve a certain technical problem follows the implementation of problem solving in practice. During the workshop, a group of students are offered, as a mini project, to develop a program for visualization of signals using a digital oscilloscope based on the AVR microcontroller [8]. Particular attention is paid to the questions of approximation, improvement of the speed and stability of the shape of impulses.

Figure 6 shows examples of work on the study of transient processes in circles of the second order.

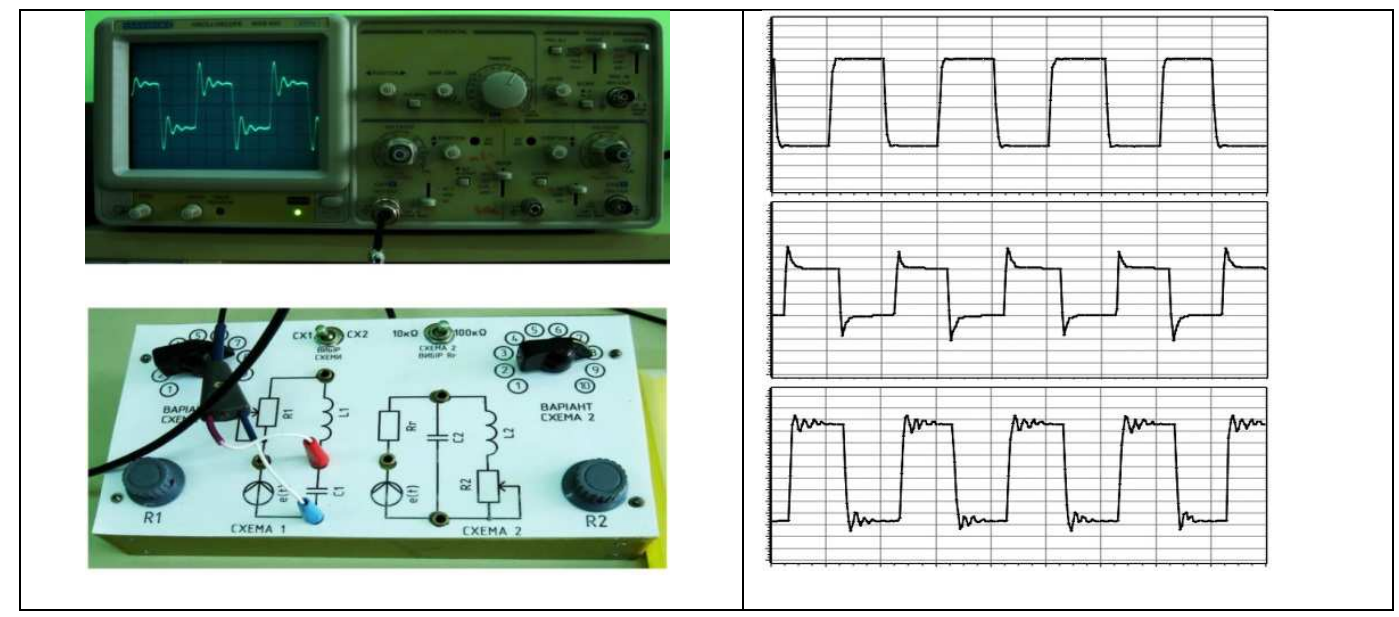

Figure 6. Visualization of the signal on analog and digital oscilloscopes

The value of such laboratory work consists in the interdisciplinary combination of skills in practice. Microcontroller programming that is carried out requires knowledge of the discipline "Architecture of microprocessor systems". Hardware interface that is created requires theory of "Electronics". Appropriate functions are used for decomposing signals into elementary components and their analysis uses "Algebra", as well as a program for processing and visualization of signals uses "Computer Graphics".

\subsection{Implementation of expert systems in the design of laboratory work}

The application of additional software in distance learning systems improves their functioning and allows them to create additional tools for designing labs and further testing. The purpose of computer training systems is mainly to deliver information to the student, as well as to check the student's ability to reproduce this information in original form. But the processing of information and its transformation into skills must be an active process. As a result of this interaction information is integrated with the knowledge already possessed by the student. 
Expert systems can be effective learning tools. An expert system is a computer software that embodies the experience of an expert based on their knowledge in a particular field. An expert system based on the processing of this knowledge can provide intelligent advice, make decisions at expert level and optionally explain how any solution was arrived at.

Each expert system consists of three parts: a very large database of recent data, a subsystem for constructing questions and a set of rules to derive conclusions. Some expert systems contain information about the method used for construction of solutions [10].

In the field of education, it is possible to allocate three groups of approaches for the study and development of expert systems. The first group can include studies relevant to the theoretical and pedagogical aspects of the application of expert systems in education. The second group is the development of specific expert education systems in cooperation with teachers based on well-known technologies. The third group includes the study of new approaches to development of expert systems in education. An analysis of the use of expert systems in the open learning showed that this direction is only developing. It is evidenced by a small number of publications in the specified problem area. Publications in this area are mainly foreseeable.

Expert systems in the engineering education are used to construct a knowledge base with data on teaching methods for the formation of professional and methodological skills and for formation of individual adaptive tasks. Moreover, for each level, a certain set of questions is selected. Expert systems provide the opportunity to structure the learning content in accordance with the analysis of responses from students' independent work. In case of distributed expert systems, the analysis of knowledge quality is performed by a dedicated expert system of knowledge analysis. Such a system makes it possible to evaluate knowledge based on mathematical methods of decision making and statistical analysis, for example, to compare the knowledge of the average student and the best student in a particular group. In this case, the results of the test give an opportunity to explore the dynamics of student training and to monitor activities. Such systems provide an opportunity to implement a flexible model of education, taking into account individual student learning rates [11].

Modern methods of computer technologies and expert systems provide an opportunity to increase the level of acquiring practical skills and realize the possibility of adaptive testing. This allows the teacher to diversify the options for the implementation of laboratory work. With the help of an adaptive scheme, it is possible to implement an interactive selection of modes, samples or devices. The application of an expert system for choosing an algorithm for design of laboratory work takes into account the type of work and offers a type of virtual instruments, interactive tasks and adaptive tests.

Very often, under the expert system teachers understand the implementation of testing and expertise of students' knowledge in the system of distance learning. A.V. Zubov and T.S. Denisova [12] have described examples of expert Internet systems for distance learning. The system has the opportunity to conduct training and certification, to analyze the effectiveness of learning based on tests developed by experts. In distance learning systems, there is the possibility of conducting an expert assessment of knowledge based on the test tasks developed by experts. At the same time, distance-learning technologies require the use of many subsystems to lift routine load from organizers and tutors. This load increases due to the fact that a person chooses the speed and time of learning. Individualization requires the availability of a developed automated system of "intelligent" hints, assistance and advice throughout the time of distance learning using different teaching methods and techniques such as lectures, practical classes, laboratory activities, project events and webinars. Only unique questions are addressed to the teacher-expert. It is possible to conclude that such intellectual subsystems can be organized on various theoretical and software concepts in the form of individual modules integrated in the system. The subsystems have different intellectual 
loadings: it is sufficient to use traditional logic in the process of design of a particular subsystem. In another case, it is convenient to develop a subsystem with a fuzzy logic.

In the electronic version of the laboratory work, a student must be able to perform the same types of tasks as in a real laboratory. With the help of a virtual learning environment a student is able to get acquainted with the problem statement and to study the theoretical material. When self-testing of knowledge is successfully completed, the student gets permission to familiarize with the scheme of conducting an experiment or the procedure for performing laboratory work. In order to study the technological processes and the principles of equipment operation, learning video demonstrations in combination with computer animation are widely used. After familiarizing with the scheme of conducting the experiment or the steps of the laboratory work, the student should also take a test. After the testing it is possible to proceed to the task. Corresponding data can be selected from the database of real measurements. These data can also be used to create a virtual simulator of laboratory work. In this case, in the software of the automated measuring system, the subroutine for obtaining data from the corresponding interface is replaced by a subroutine for obtaining data from the database.

Adaptive testing tools can diversify the choice of options for laboratory work. An adaptive scheme allows implementing an interactive selection of parameters, modes, samples, devices, etc. An expert system can be applied for selection of an algorithm for designing laboratory work which takes into account the type of work (estimation, direct or indirect measurements, research, simulation, automatic design, programming, etc.). It offers the type of interactive tasks, virtual instruments and adaptive tests. With the help of adaptive testing, it is possible to create new tests with different sets of tasks, which are selected based on passing the previous test by the student during the laboratory work. In the easiest way, with the right choice of answers, the student goes to the next step of the laboratory work, otherwise, they are invited to learn the theoretical material one more time and take a new test. The number of variants of laboratory work can be expanded.

The feedback system gives the opportunity to discuss the issues at the forum and send reports on laboratory work for verification. The expert system can offer the optimal choice of tools type, control questions, practical tasks, scenarios, depending on the type of laboratory work.

Let us discuss some cases of laboratory works and tasks for testing on the example of the discipline "Discrete Mathematics".

Laboratory activity \#1.

To study the methods of numerical simulation of basic operations on sets (intersection, union, difference, symmetric difference) and compile a computer program for performing these operations over two finite sets.

After studying the theoretical material and familiarizing with the laboratory work, the student takes a test. Depending on the test results it becomes possible to get acquainted again with the theoretical material (the next test contains a smaller number of questions), or to switch to the practical part of the laboratory work. During lab activity the student must formulate an algorithm with a block diagram and write the corresponding software code. The student can choose a programming language to create a user interface and source code for the program. They can also choose which types of operations on sets need to be implemented.

Test task \#1.

Find the conjunctive normal form of the Boolean function $\left(x_{1} \vee \overline{x_{2}}\right) \rightarrow x_{3}$.

The student is asked to choose the correct answer from the proposed:
1. $\left(\overline{x_{1}} \wedge x_{3}\right) \vee\left(x_{2} \wedge x_{3}\right)$
2. $\left(\overline{x_{1}} \vee x_{3}\right) \wedge\left(x_{2} \vee x_{3}\right)$
3. $\left(x_{1} \vee x_{3}\right) \wedge\left(\overline{x_{2}} \vee x_{3}\right)$;
4. $\left(\overline{x_{1}} \vee x_{3}\right) \wedge\left(\overline{x_{2}} \vee x_{3}\right)$. 
If the student selects (2), they go to the next step. Otherwise, the student is invited to learn the theoretical content and to take the test of knowledge of the Boolean algebra laws. With the correct answers to the tasks, the corresponding test task may not be included in the test. It depends on the system settings. Laboratory work, tests and tasks can be complicated or varied. The feedback system provides an opportunity to discuss the issues at the forum and to send reports on the student's performance for the teacher's verification.

\section{DISCUSSION OF THE RESULTS}

Active learning requires a careful selection of tasks for students. It can be implemented in a variety of forms, such as problem-based learning, project-based learning, study of discovery, survey-based learning, simulation-based learning, game-based learning, and discussion-based learning [13].

Expert systems make it possible to select optimal tasks for laboratory work. In creating tasks that require information skills, the following aspects are taken into account: determination of the information problem, determination of the relevance of the various information sources, searching for data using the relevant technologies, localization, obtaining and evaluating information, searching and processing of the data obtained from electronic knowledge testing systems.

Active learning involves students' active role in the process of obtaining new knowledge or skills. It is also important that active training is often carried out in teams, especially during laboratory work. An important component is the integration of software with hardware systems and devices. Students who are actively studying are likely to recall information in various situations related to solving specific interdisciplinary tasks in practice. While studying, students learn not only complex mathematical tasks and projects with interdisciplinary approach, but also receive a complex of non-specialized, professional skills. Applied information technologies are responsible for high productivity and successful participation in the educational process. During the course of laboratory work, such skills include, for example, information skills, presentation skills, teamwork skills and project design skills.

As a result of the research, a computer information system was proposed for planning and implementation of laboratory work, analysis of results and testing of knowledge. The database stores relevant scenarios and tasks developed in accordance with the active learning methodology. Selected users can create teaching scripts by compiling tasks. E-learning systems, expert systems and proposed algorithms provide an opportunity to optimally determine the tasks and subtasks of the discipline, to draw up a plan, to allocate tasks for independent study and work in class, to identify problem issues for discussion in groups, to monitor progress.

The laboratory work scenario is based on specific tasks. During such lab activity students perform the work on specific skills. Each task is a result of activities with specific consequences. Information and communication technologies in laboratory work allow developing a fundamentally new educational design of electronic training courses with professional multimedia presentations of complex abstract or technical processes, to form and consolidate practical skills in applying previously acquired knowledge.

The developed tools and proposed methods can help teachers to use information and communication technologies and electronic systems in the teaching of mathematics and natural sciences.

\section{CONCLUSIONS}

1. Learning Management Systems, electronic tutorials and electronic laboratories greatly facilitate the process of obtaining knowledge. Computer-based testing tools are widely used for 
assessment of students' knowledge both at the stage of self-examination and during final tests. They significantly facilitate the verification of solutions of a large number of mathematical examples while working with a wide audience of students. Since most of the Learning Environments are written on an open source code, it is possible to adapt them to the specifics and needs of higher education institutions. In the preparation of test tasks, it is important to choose the right type of tasks that will be used while checking knowledge about a particular object of study. For an objective assessment of the correctness of the tasks in mathematical disciplines, it is worth using open questions. In the proposed approach, the modification of the formula editor involves the creation of templates for entering formulas and the use of the indexing algorithm of the expression elements. It makes possible to avoid ambiguity when entering students' responses. Tasks with computer verification of an analytical symbolic expression can be applied to automate the verification of skills and knowledge in natural sciences, in particular physics and mathematics, by appropriate modification of the template.

2. Since the teaching of mathematical disciplines to students of information science, physics, chemistry and biology is more focused on the practical application of the material, a training course (methodological electronic tasks) was developed, aimed to improve the assimilation of material from algebra and geometry. The sections of algebra and geometry most widely used in practice were selected. This course helps to solve typical application problems, such as finding a solution of systems of linear equations, etc. Such electronic resources can be shared with other educational institutions within the framework of mobility programs. A general approach to the construction of courses of this type was developed.

3 . The use of an interdisciplinary approach in the development of laboratory works in natural sciences is a good method that promotes the ability of the student to use the knowledge gained in the study of other sciences. The implementation of the problem based learning for processing and visualization of signals in electronic devices is discussed. It is combined with measurements and solving of problems in algebra and programming.

4. An essential feature of higher education is the complexity of quantitative evaluation of learning and management processes. Ambiguous evaluation of these processes makes it necessary to find solutions of the classical educational problems not only by classical methods. One of such methods is the implementation of expert systems. Expert systems in education are used to optimize the process of development of laboratory activities of adaptive type and the formation of individual test tasks for verification of theoretical knowledge. In the article, the application of the expert system is illustrated on the example of the discipline "Discrete Mathematics". Expert systems provide the opportunity to structure the training material in accordance with the analysis of responses in the course of students' independent work. Also, these systems can offer a set of competencies that students need to master for the development of a particular method or software product. The experience of working with expert systems makes it possible to take into account students' individual competence and their professional advantages. It increases the efficiency of students' training, improves their cognitive activity and motivation.

\section{REFERENCES (TRANSLATED AND TRANSLITARETED)}

[1] V. Avanesov, Scientific problems of knowledge test control. Moscow, Russia: MGTA, 1994, 136 p. (in Russian)

[2] “Firemath - The MathML-Editor.” [Online]. Available: http://www.firemath.info/. Accessed on: May 13, 2019. (in English)

[3] YU. Zharkikh, S. Lysochenko, B. Sus., O. Tretyak, Computer technology in education. Tutorial. Kyiv.: Publishing Polygraphic Center "Kyiv University", 2012, 239 p. (in Ukrainian)

[4] K. L. Huff and S. G. Sireci, "Validity Issues in Computer-Based Testing," in Educational Measurement: Issues and Practice, 2001, vol. 20, no. 3, pp. 16-25, doi: 10.1111/j.1745-3992.2001.tb00066.x. (in English) 
[5] N. Tmienova and B. Sus, "Features of computer testing on mathematical disciplines in electronic learning environments," 2013 5th Scientific and Practical Conference "Innovative Computer Technologies in Higher School", pp. 52-55. (in Ukrainian)

[6] "Conrad Wolfram: Teaching kids real math with computers | TED Talk." [Online]. Available: https://www.ted.com/talks/conrad_wolfram_teaching_kids_real_math_with_computers. Accessed on: May 13, 2019. (in English)

[7] B. Sus, N. Tmienova, I. Revenchuk, and V. Vialkova, "Development of Virtual Laboratory Works for Technical and Computer Sciences," in Information and Software Technologies, Cham, 2019, pp. 383-394, doi: 10.1007/978-3-030-30275-7_29. (in English)

[8] CaffeinomaneFollow, "Girino - Fast Arduino Oscilloscope," Instructables. [Online]. Available: https://www.instructables.com/id/Girino-Fast-Arduino-Oscilloscope/. Accessed on: May 13, 2019. (in English)

[9] S. K. Khanna, A. Kaushik, and M. Barnela, "Expert systems advances in education," 2010 National Conference on Computational Instrumentation CSIO Chandigarh. India, pp. 109-112. (in English)

[10] P. Jackson, Introduction to Expert Systems. Wokingham, England; Reading, Mass: Addison-Wesley Pub, 1999, 524 p. (in English)

[11] N. Baranova, "On the issue of the use of expert systems in continuous pedagogical education," Education and Science, 4, p. 24-28, 2008. (in Russian)

[12] A. Zubov and T. Denisova, Creation of complex expert Internet systems for distance learning. Informatization of education and science. M.: State Research Institute of Information Technologies and Telecommunications, 2010, 187 p. (in Russian)

[13] H. Koppelman. "Active learning in asynchronous distance education". IADIS International Conference on Cognition and Exploratory Learning in Digital Age (CELDA Proceedings 2009). [Online]. Available: http://www.iadisportal.org/celda-2009-proceedings. Accessed on: May 13, 2019. (in English)

Text of the article was accepted by Editorial Team 15.01.2019

\title{
УДОСКОНАЛЕННЯ ТЕХНОЛОГІЙ ОЦІНЮВАННЯ ЗНАНЬ ТА ВМІНЬ СТУДЕНТІВ ФІЗИКО-МАТЕМАТИЧНИХ СПЕЦІАЛЬНОСТЕЙ В УМОВАХ ЕЛЕКТРОННОГО НАВЧАННЯ
}

\author{
Тмснова Наталія Пилипівна \\ кандидат фізико-математичних наук, доцент кафедри інтелектуальних та інформаційних систем \\ Київський національний університет імені Тараса Шевченка, м. Київ, Україна \\ ORCID ID 0000-0003-1088-9547 \\ tmyenovox@gmail.com \\ Сусь Богдан Богданович \\ кандидат фізико-математичних наук, асистент кафедра нанофізики конденсованих середовищ \\ Київський національний університет імені Тараса Шевченка, м. Київ, Україна \\ ORCID ID 0000-0002-2566-5530 \\ bnsuse@gmail.com
}

\begin{abstract}
Анотація. Незважаючи на успішне вирішення проблеми отримання освітньої інформації під час електронномого навчання, тестування отриманих знань все ще залишається актуальним завданням. Розроблено принципи оцінювання знань при тестуванні 3 математичних дисциплін в середовищі електронного навчання. Запропоновано алгоритм компонентного аналізу формульних виразів та їх індексування для автоматичного аналізу формул. Такий підхід дозволяє урізноманітнити типи питань при послідовній перевірці знань в комп’ютерних системах. Модифікація редактора формул передбачає створення шаблонів для введення формул та використання алгоритму індексації елементів виразу, що дає можливість уникнути неоднозначності при введенні відповіді студентами. Завдання 3 комп'ютерною перевіркою аналітичного символьного виразу можуть бути застосовані для автоматизації перевірки вмінь і знань 3 природничих дисциплін, зокрема фізики, математики, шляхом відповідної модифікації шаблону.

Розвиток інформаційних технологій призвів до розробки нових моделей викладання i навчання, особливо в галузі математичних наук. Проілюстровано, що при виконанні експериментальних лабораторних робіт з технічних дисциплін особливо ефективними $\epsilon$ ті, які поєднують використання знань і навичок, набутих при вивченні інших суміжних дисциплін. Показано, що великі перспективи мають дослідження саме на основі міждисциплінарної взаємодії.
\end{abstract}


Крім того, обговорюється досвід застосування та переваги експертних систем у системі відкритої освіти для вдосконалення навчально-виховного процесу та підвищення його ефективності. Запропоновано використовувати експертні системи при проєктуванні лабораторних робіт і тестів. Також показано, що експертні системи доцільно використовувати для оптимізації процесу створення лабораторних робіт адаптивного типу та формування індивідуальних тестових завдань. Застосування експертної системи проілюстровано на прикладі дисципліни «Дискретна математика».

Ключові слова: тестування; автоматичний аналіз; ІТ-технології; міждисциплінарність; електронне навчання; експертні системи.

\title{
УСОВЕРШЕНСТВОВАНИЕ ТЕХНОЛОГИЙ ОЦЕНИВАНИЯ ЗНАНИЙ И УМЕНИЙ СТУДЕНТОВ ФИЗИКО-МАТЕМАТИЧЕСКИХ СПЕЦИАЛЬНОСТЕЙ В УСЛОВИЯХ ЭЛЕКТРОННОГО ОБУЧЕНИЯ
}

\author{
Тменова Наталья Филипповна \\ кандидат физико-математических наук, доцент кафедры интеллектуальных и информационных систем \\ Киевский национальный университет имени Тараса Шевченко, г. Киев, Украина \\ ORCID ID 0000-0003-1088-9547 \\ tmyenovox@gmail.com
}

\section{Сусь Богдан Богданович}

кандидат физико-математических наук, ассистент кафедры нанофизики конденсированных сред Киевский национальный университет имени Тараса Шевченко, г. Киев, Украина

ORCID ID 0000-0002-2566-5530

bnsuse@gmail.com

\begin{abstract}
Аннотация. Несмотря на успешное решение проблемы получения образовательной информации при электронном обучении, тестирование полученных знаний все еще остается актуальной задачей. Разработаны принципы оценивания знаний при тестировании по математическим дисциплинам в среде электронного обучения. Предложен алгоритм компонентного анализа формульных выражений и их индексирования для автоматического анализа формул. Такой подход позволяет разнообразить типы вопросов при последовательной проверке знаний в компьютерных системах. Модификация редактора формул предусматривает создание шаблонов для ввода формул и использования алгоритма индексации элементов выражения, что дает возможность избежать неоднозначности при введении ответов студентами. Задания с компьютерной проверкой аналитического символьного выражения могут быть применены для автоматизации проверки умений и знаний по естественным дисциплинам, в частности, физики, математики, путем соответствующей модификации шаблона.

Развитие информационных технологий привело к разработке новых моделей преподавания и обучения, особенно в области математических наук. Проиллюстрировано, что при выполнении экспериментальных лабораторных работ по техническим дисциплинам особенно эффективными являются те, которые сочетают использование знаний и навыков, приобретенных при изучении других смежных дисциплин. Показано, что большие перспективы имеют именно исследования на основе междисциплинарного взаимодействия. Кроме того, обсуждается опыт применения и преимущества экспертных систем в системе открытого образования для усовершенствования учебно-воспитательного процесса и повышения его эффективности. Предложено использовать экспертные системы при проектировании лабораторных работ и тестов. Также показано, что экспертные системы целесообразно использовать для оптимизации процесса создания лабораторных работ адаптивного типа и формирования индивидуальных тестовых заданий. Применение экспертной системы проиллюстрировано на примере дисциплины «Дискретная математика».
\end{abstract}

Ключевые слова: тестирование; автоматический анализ; IT-технологии; междисциплинарность; электронное обучение; экспертные системы.

\section{(cc) EY-NC-SA}

This work is licensed under Creative Commons Attribution-NonCommercial-ShareAlike 4.0 International License. 